\title{
Expression and Sexual Dimorphism of Galanin Messenger Ribonucleic Acid in Growth Hormone-Releasing Hormone Neurons of the Rat during Development*
}

\author{
HENRIETTE A. DELEMARRE-VAN DE WAAL $\dagger$, KIMBERLY A. BURTON, \\ EMILIA B. KABIGTING, ROBERT A. STEINER, AND DONALD K. CLIFTON \\ Departments of Obstetrics and Gynecology (R.A.S., D.K.C.) and Physiology and Biophysics (K.A.B., E.B.K., \\ R.A.S., D.K.C.), and the Population Center for Research in Reproduction (R.A.S., D.K.C), University of \\ Washington, Seattle, Washington 98195; and the Department of Pediatrics, Free University Hospital \\ (H.A.D.-v.d.W.), Amsterdam, The Netherlands
}

\begin{abstract}
In the rat, the secretion of $\mathrm{GH}$ is episodic and sexually dimorphic. The development and regulation of this patterning of $\mathrm{GH}$ secretion are governed by the reciprocal influence of the hypothalamic peptide somatostatin and GH-releasing hormone (GHRH). Galanin is a neuropeptide that is colocalized with GHRH in hypothalamic neurons and is thought to be involved in generating the episodic pattern of $\mathrm{GH}$ secretion. We hypothesized that galanin mRNA expression in GHRH neurons increases over development in both sexes, and that in the adults, galanin expression in GHRH neurons is greater in males than in females. To test these hypotheses, we used a double label in situ hybridization procedure to detect and measure galanin mRNA expression in GHRH neurons in the rat brain. GHRH mRNA-positive cells were visualized by an alkaline phosphatase color reaction, and galanin mRNA levels were measured by counting autoradiographic grains over individual GHRH mRNA-positive cells. Galanin mRNA coexpression was found in GHRH mRNA-containing cells of the arcuate nucleus, periarcuate area, and ventromedial hypothalamus. In both males and females there was a significant increase in galanin mRNA in GHRH neurons over development. Galanin mRNA levels in GHRH neurons of 10- and 25-day-old rats were higher in females than in males [10day-old: females, $12 \pm 2$; males, $6 \pm 1$ grains/cell $(P<0.05)$; 25-dayold: females, $28 \pm 4$; males, $15 \pm 3$ grains/cell $(P<0.02)$ ]. In adults
\end{abstract}

(70 days), galanin mRNA levels in GHRH neurons were significantly higher in males than in females (males, $54 \pm 4$; females, $32 \pm 3$ grains/ cell; $P<0.005$ ). In the adult rat, galanin mRNA levels in the individual hypothalamic areas exhibited a significant sexual dimorphism in the arcuate nucleus and periarcuate area, with higher levels in the male, whereas no sexual dimorphism was observed in the ventromedial hypothalamus. To determine whether galanin gene expression is influenced by circulating levels of testosterone, we measured galanin mRNA levels in castrated male rats with and without testosterone replacement. Castration reduced galanin message levels in GHRH neurons (intact, $73 \pm 6$; castrate, $57 \pm 4$ grains/cell), and although this reduction was not statistically significant $(P=\sim 0.07)$, testosterone replacement significantly increased galanin message content (castrate/sham, $58 \pm$ 4 grains/cell; castrate plus testosterone replacement, $77 \pm 5$ grains/ cell; $P<0.02$ ) to intact levels (intact, $73 \pm 6$ grains/cell). In summary, galanin message expression in GHRH neurons of both male and female rats increases over development. In adults, male GHRH neurons contain higher levels of galanin mRNA than those of females, and this difference is probably due at least in part to differences in circulating testosterone levels. These observations support the hypothesis that sexual dimorphism in the GH secretory system is related to sexdependent differences in galanin gene expression of GHRH neurons. (Endocrinology 134: 665-671, 1994)
$\mathrm{T}$ HE SECRETORY patterns of GH in the rat are sexually dimorphic (1). The male GH pattern has characteristically low basal levels and high amplitude pulses at regular 3- to 4-h intervals, whereas the female $\mathrm{GH}$ pattern has higher basal levels, and the pulses are less pronounced, more frequent, and irregular (2-4). In both sexes, GH pulses are the result of coordinated discharges of somatostatin (SS) and $\mathrm{GH}$-releasing hormone (GHRH) from neurons located primarily in the periventricular and arcuate nuclei of the hypothalamus, respectively. The sexual dimorphism in $\mathrm{GH}$

Received September 3, 1993.

Address all correspondence and requests for reprints to: Dr. Donald K. Clifton, Department of Obstetrics and Gynecology, RH-20, University of Washington, Seattle, Washington 98195.

* This work was supported by USPHS (NIH) Grants HD-12625, HD12629, and HD-29039 and a grant from the Dutch Praeventiefonds, The Querido Stipendium 1991.

† Permanent address: Department of Pediatrics, Free University Hospital, P.O. Box 7057, 1007 MB Amsterdam, The Netherlands. secretion is, therefore, probably due at least in part to differences in the activity of these hypothalamic SS and GHRH neurons $(5,6)$.

Galanin is a neuropeptide that is colocalized with GHRH in hypothalamic neurons (7) and is thought to play a role in the physiological regulation of $\mathrm{GH}$ secretion. Administration of galanin stimulates GH secretion (8-10), and this effect is thought to be mediated by galanin induction of GHRH secretion (11). Infusion of antiserum to galanin evokes an increased frequency of $\mathrm{GH}$ pulses and a diminished $\mathrm{GH}$ pulse amplitude, converting the male $\mathrm{GH}$ pulse pattern to one that appears more like that of the female (12). These observations suggest that the physiological role of galanin may be to enhance GHRH secretory activity, and that galanin's differential expression may contribute to the sexually dimorphic pattern of GH secretion.

In this study we had three objectives. The first was to confirm that GHRH neurons actually synthesize and not 
merely concentrate the peptide galanin. We examined this by performing double labeling in situ hybridization to confirm the presence of galanin mRNA in GHRH neurons. A second objective was to test the hypothesis that galanin mRNA expression in GHRH neurons is greater in males than females and to determine when during development the dimorphism becomes evident. We accomplished this by comparing cellular galanin mRNA levels in GHRH neurons between male and female rats at different developmental stages. The third objective was to determine whether the circulating levels of testosterone in the adult male influence galanin mRNA expression in GHRH neurons and could thus be implicated for a role in the manifestation of sexual dimorphism in GH pulse patterns. We tested this hypothesis by examining the effects of castration and testosterone replacement on galanin mRNA levels in GHRH neurons in the adult male rat.

\section{Materials and Methods}

\section{Animals}

Adult (70-day-old) and juvenile (25-day-old) Sprague-Dawley rats were purchased (Tyler Laboratories, Bellevue, WA) and housed under light-controlled conditions (12-h light, 12-h dark cycle), with lights on at $0700 \mathrm{~h}$. The animals were given free access to tap water and rat chow. For 5- and 10-day-old neonatal rats, pregnant Sprague-Dawley rats were obtained from the same source and allowed to give birth. The pups remained with their mothers until the end of the study.

\section{Experimental design}

Exp 1: galanin mRNA in GHRH neurons during development and between sexes. Galanin mRNA levels in GHRH mRNA-positive cells of male and female rats were compared among groups of neonatal (10-day-old), juvenile (25-day-old), and adult (70-day-old) animals. Each group contained five animals. The adult females were killed on diestrous day 1; all animals were killed between $0900-1100 \mathrm{~h}$.

Exp 2: sexual dimorphism of galanin in GHRH neurons of young neonatal rats. Galanin mRNA levels in GHRH mRNA-positive cells were compared in 5-day-old male and female pups (four animals per group). Animals were killed between $1000-1100 \mathrm{~h}$.

Exp 3: testosterone regulation of galanin mRNA in GHRH neurons. Galanin mRNA levels in GHRH mRNA-positive cells were compared among adult male rats that were sham castrated $(n=6)$, castrated $(n=6)$, or castrated and treated with testosterone $(n=5)$. The animals were killed 5 days after surgery between $1000-1300 \mathrm{~h}$.

\section{Surgery and steroid treatment}

Castrations and sham castrations were performed while maintaining the animals under sedation with ether anesthesia. Immediately after castration, the animal received a $30-\mathrm{mm}$ Silastic capsule (od, $3.18 \mathrm{~mm}$; id, $1.57 \mathrm{~mm}$; Dow-Corning, Midland, MI) that was either empty or filled with crystalline testosterone and sealed at both ends with Silastic cement. The capsules were washed carefully in running tap water and incubated for several days in PBS before implantation.

\section{Tissue preparation}

The animals were asphyxiated with carbon dioxide generated from dry ice and immediately decapitated. The brains were removed, rapidly frozen on dry ice, and stored intact at $-80 \mathrm{C}$ until processed for the in situ hybridization procedure. The sex of the neonatal animals was determined by examination of the internal sex organs after death.
Immediately before slicing, the brains were allowed to equilibrate in the cryostat chamber $(-20 \mathrm{C})$. Coronal sections were cut at $20 \mu \mathrm{m}$ and thaw-mounted onto poly-L-lysine-coated $(50 \mu \mathrm{g} / \mathrm{ml})$ slides. Brain sections were cut beginning rostrally at the decussation of the anterior commissure and continuing caudally to the end of the arcuate nucleus. Four sets of slices were collected; every fourth slice was placed into a given set. Slides were stored in air-tight boxes at $-80 \mathrm{C}$ until hybridization histochemistry was performed. One set of slides from each animal was analyzed in this study.

\section{GHRH cRNA probe synthesis and labeling}

The prghrf-2 plasmid was obtained from Dr. Kelly Mayo (13). This plasmid consists of a 360-basepair (bp) EcoRI-Sall fragment of a rat GHRH cDNA clone inserted into the vector pUC8. The EcoRI-SalI fragment includes the coding region for GHRF-43, the coding region for a 30-amino acid peptide of unknown function, a 105-nucleotide 3'untranslated region, and the poly(A) tail. A 198-bp EcoRI-HindIII fragment including the entire GHRH-43 coding sequence as well as a portion of the sequence for the 30-amino acid peptide was subcloned into the transcription vector (pGEM4; Promega Biotec, Madison, WI). The cDNA was linearized by EcoRI and then a digoxigenin-labeled antisense cRNA probe was made in vitro from the linearized DNA with the following reagents: $400 \mu \mathrm{M}$ digoxigenin-11-UTP (Boehringer Mannheim, Indianapolis, IN); $100 \mu \mathrm{M}$ unlabeled UTP; $500 \mu \mathrm{M}$ GTP, ATP, and CTP; and T7 polymerase. Residual DNA was digested with DNAase. The cRNA probe was separated on a Sephadex G-50 column.

\section{Galanin probe synthesis and labeling}

The rat galanin riboprobe plasmid was obtained from Dr. Maria E. Vrontakis (14). The plasmid consisted of a $680-\mathrm{bp}$ segment of rat galanin cDNA inserted into the EcoRI site of Bluescript M13(-) (Stratagene, San Diego, CA). After HindIII was used to linearize the CDNA, the ${ }^{35} \mathrm{~S}-$ labeled antisense riboprobe was generated through the use of T7 RNA polymerase in the presence of $25 \%\left[{ }^{35} \mathrm{~S}\right] \mathrm{UTP}$. The probe was denatured at $80 \mathrm{C}$, rapidly cooled, and added to hybridization buffer to obtain a final concentration of $0.3 \mu \mathrm{g} / \mathrm{ml} \cdot \mathrm{kilobase}$. This corresponded to a specific activity of the galanin riboprobe that was approximately $6.1 \times 10^{8} \mathrm{dpm} /$ $\mu \mathrm{g}$ for $\operatorname{Exp} 1$ and $4.0 \times 10^{8} \mathrm{dpm} / \mu \mathrm{g}$ for $\operatorname{Exp} 2$ and 3 .

\section{In situ hybridization}

In situ hybridization was performed as previously described (15). Briefly, after fixation with $4 \%$ paraformaldehyde, tissue sections were rinsed twice in phosphate buffer for $10 \mathrm{~min}$ each and then dipped in water, followed by $0.1 \mathrm{M}$ TEA $(0.1 \mathrm{M}$ triethanolamine and $5 \mathrm{M} \mathrm{NaCl}, \mathrm{pH}$ 8.0). After 10 -min treatment in $0.25 \%$ acetic anhydride in $0.1 \mathrm{M}$ TEA, the slides were rinsed in $2 \times \mathrm{SSC}(1 \times \mathrm{SSC}=150 \mathrm{mM} \mathrm{NaCl}$ and $15 \mathrm{~mm}$ $\mathrm{Na}$ citrate), dehydrated through a series of ethanol washes, delipidated in chloroform, and air dried. Before the hybridization step, $40 \mu \mathrm{l}$ of a mixture containing hybridization buffer, $12.5 \mathrm{~mm}$ dithiothreitol (DTT), and $20 \%$ denatured yeast total RNA were applied to each section, and the tissue was covered with parafilm and incubated at $60 \mathrm{C}$ in moist chambers for $2 \mathrm{~h}$. The slides were then rinsed in $2 \times$ SSC and dehydrated with ethanol, and $45 \mu \mathrm{l}$ of the probe mixture were applied to each slide. The probe mixture consisted of hybridization buffer and a denatured combination of RNAs including the $\left[{ }^{35} \mathrm{~S}\right]$ galanin probe, the digoxigeninGHRH probe, and yeast total RNA. Coverslips were placed on the slides; they were sealed with rubber cement and incubated at $60 \mathrm{C}$ in moist chambers overnight. The next day, after removal of the coverslips, the slides were washed twice (15 min each) in $4 \times$ SSC containing $2 \mathrm{mM}$ DTT. This was followed by treatment with $30 \mu \mathrm{g} / \mathrm{ml}$ RNAse in RNAse buffer (10 mM Tris, $\mathrm{pH} 8.0 ; 1 \mathrm{mM}$ EDTA; and $50 \mathrm{mM} \mathrm{NaCl}$ ), rinses with RNAse buffer (with $1 \mathrm{~mm}$ DTT) and $2 \times$ SSC, and a hot shaking wash at $65 \mathrm{C}$ in $0.1 \times$ SSC with $1 \mathrm{~mm}$ DTT for $30 \mathrm{~min}$. After a final wash with $0.1 \times$ SSC, the slides were treated with blocking buffer $(2 \times$ SSC with $0.05 \%$ Triton $X-100$ and $2 \%$ normal sheep serum) for $1 \mathrm{~h}$. 


\section{Digoxigenin staining}

Each slice was covered with parafilm and incubated with $100 \mu \mathrm{l}$ of an antidigoxigenin antibody fragment conjugated to alkaline phosphatase [Boehringer Mannheim; diluted 1:1000 in buffer $1(100 \mathrm{~mm}$ Tris$\mathrm{HCl}$ and $150 \mathrm{mM} \mathrm{NaCl}, \mathrm{pH} 7.5$ ) containing $1 \%$ normal sheep serum and $0.3 \%$ Triton $X-100]$. After 10 -min washes with buffer 1 and buffer 2 (100 mM Tris, $\mathrm{pH} 9.5 ; 50 \mathrm{~mm} \mathrm{MgCl}_{2}$, and $100 \mathrm{~mm} \mathrm{NaCl}, \mathrm{pH} 9.5$ ), respectively, the slides were incubated in buffer 2 containing nitrobluetetrazolium-chloride $(340 \mu \mathrm{g} / \mathrm{ml})$, 5-bromo-4-chloro-3-indolyl-phosphate $(175 \mu \mathrm{g} / \mathrm{ml})$, and levamisole $(240 \mu \mathrm{g} / \mathrm{ml})$ overnight to generate a water-insoluble color reaction product. Then the slides were washed twice in buffer 3 ( $10 \mathrm{~mm}$ Tris- $\mathrm{HCl}$ and $1 \mathrm{~mm}$ EDTA, $\mathrm{pH} 8.0)$, dehydrated in ethanol, and air dried. To prevent chemographic artifacts in the autoradiographic steps, the slides were dipped in a solution of $3 \%$ parlodion in isoamyl acetate.

\section{Autoradiography}

The slides were dipped into NTB-2 photographic emulsion (Eastman Kodak, Rochester, NY) at $45 \mathrm{C}$, air dried, placed in light-tight boxes containing desiccant, and stored at $4 \mathrm{C}$. After 10 days, the slides were developed, and coverslips were applied.

\section{Anatomical matching}

To compare anatomically similar regions between sexes and across age groups, slides were matched according to the rat brain atlas of Paxinos and Watson (16). The basal hypothalamus containing GHRH neurons was divided into three areas of approximately equal length in the rostral-caudal plane. The first section started where the first GHRH cells appear, and the second with the rostral border of the dorsal medial nucleus. The end of the third section was where the last GHRH cells are found. The second and third sections were formed by dividing the area from the start of the second section to the end of the third section into two equal parts. Three sections were evaluated from each area (a total of nine sections per animal).

\section{Image analysis}

Anatomically matched slides were assigned a random three-letter code, alphabetized, and read in random order with an automated imageprocessing system by an operator unaware of the animal's experimental group. This system consisted of a PixelGrabber video acquisition board (Perceptics, Knoxville, TN) attached to a Macintosh $f x$ computer. Video images were obtained by a Dage model 65 camera (Dage, Inc., Michigan City, IN) attached to a Zeiss Axioskop (Zeiss, New York, NY) equipped with a $\times 40$ objective and a 100 -watt HBO mercury arc epillumination system with a polarizing cube. For each section that was analyzed, silver grains over digoxigenin-labeled GHRH cells were counted, and the anatomical locations of these cells were recorded (17). The number of grains per cell is referred to here as the mRNA signal level.

\section{Serum $L H$ and sex steroid determination}

Serum LH levels, testosterone in the male animals, and serum estradiol levels in the female animals were measured by RIA. LH was measured by a double antibody RIA with reagents obtained from the National Hormone and Pituitary Program. Testosterone was extracted from plasma samples with anhydrous ether and then measured by RIA after TLC (18). Estradiol was measured by RIA after chromatography of the plasma samples, as described by Goodman (19). The intraassay coefficients of variation were $7 \%, 10 \%$, and $7 \%$ for the $\mathrm{LH}$, testosterone, and estradiol assays, respectively.

\section{Statistical analysis}

The mean number of grains per cell for each individual animal was calculated for each area that contained GHRH mRNA-positive cells. This number of grains per cell for each animal was used to determine the mean \pm SEM for each group. Therefore, the $n$ referred to elsewhere in this report and used for statistical analysis was the number of animals in each group. For Exp 1, we tested for differences in grains per cell between sex and age by two-way analysis of variance (ANOVA). This was followed by individual one-way ANOVAs and Duncan's new multiple range test to assess changes in grains per cell over development for each sex. Differences between males and females at each age (Exp 1 and 2) were determined by Student's $t$ test. The effects of castration and testosterone treatment (Exp 3) were assessed by one-way ANOVA, followed by Duncan's new multiple range test. Differences were considered statistically significant when $P<0.05$.

\section{Results}

\section{Galanin mRNA in GHRH neurons}

GHRH mRNA-containing cells were found in the arcuate nucleus (Arc), periarcuate area (PArc), and ventromedial hypothalamus (VMH) of animals in all of the groups (Fig. 1). Evidence for the presence of galanin mRNA within GHRH cells was found in all of these areas.

\section{Galanin and GHRH mRNA coexpression in males and females over development}

Analysis of the data from Exp 1 by two-way ANOVA (age $v s$. gender) suggested that there was a significant overall change in galanin gene expression within GHRH cells over development $(P<0.0001$; Figs. 2 and 3$)$. In addition, although there were no overall differences in galanin mRNA signal levels between males and females $(P>0.7)$, there was a significant interaction between age and gender $(P<$ $0.0001)$, suggesting that developmental patterns of galanin gene expression in GHRH neurons are sexually dimorphic. Because this overall analysis indicated that there were significant effects of development and gender on galanin gene

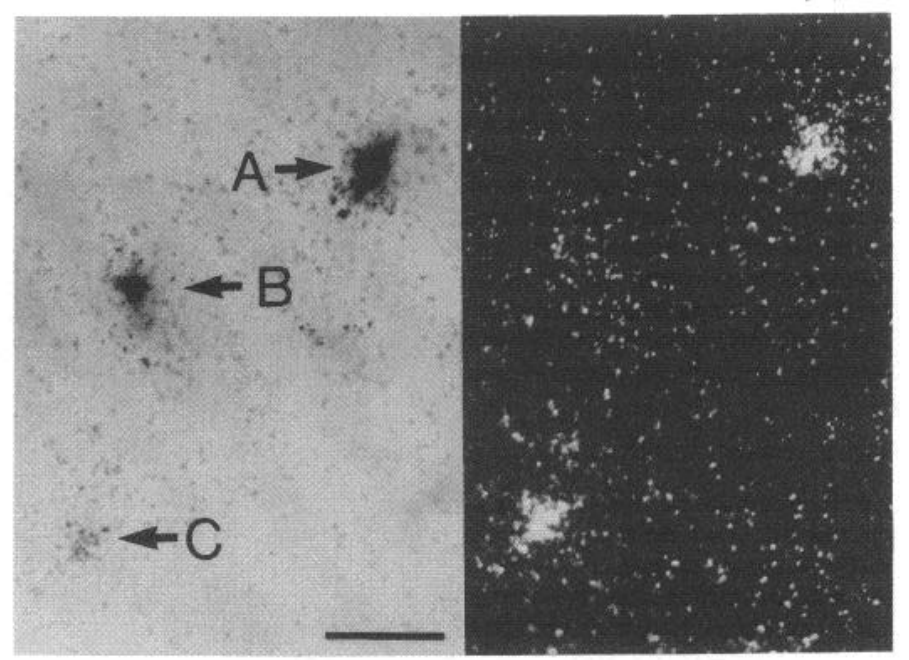

FIG. 1. Photomicrographs of neurons in the Arc under brightfield (left) and darkfield (right) illumination after double label in situ hybridization for GHRH and galanin. Under brightfield illumination, the presence of digoxigenin-labeled GHRH mRNA is indicated by dark-stained cell bodies (A and B). Silver grains from the radiolabeled galanin probe appear as black dots in brightfield and white dots in darkfield; clusters of silver grains (A and C) mark cells containing galanin mRNA. Cell $\mathrm{A}$ is double labeled for galanin and GHRH, cell B contains GHRH only, and cell $\mathrm{C}$ contains galanin only. The length of the bar at the bottom of the left panel is $50 \mu \mathrm{m}$. 


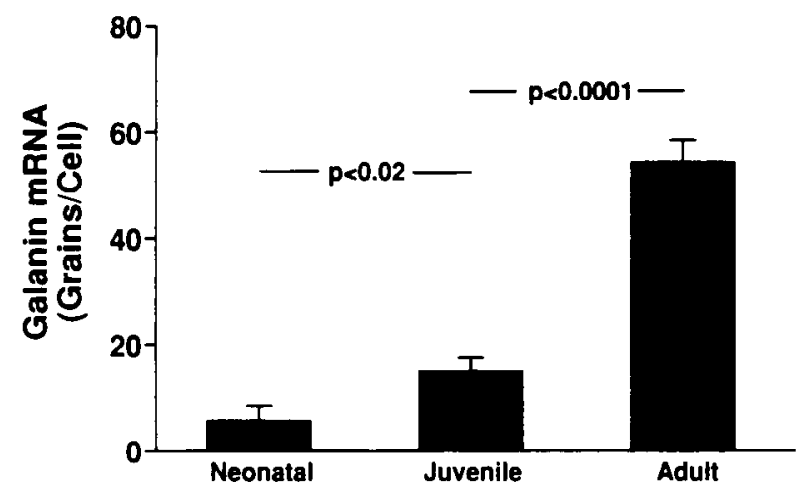

Fig. 2. Galanin mRNA levels (as reflected by grains per cell) in GHRH neurons of the male rat throughout development. The ages of rats are as follows: neonatal, 10 days; juvenile, 25 days; and adult, 70 days. Values are presented as the mean \pm SEM.

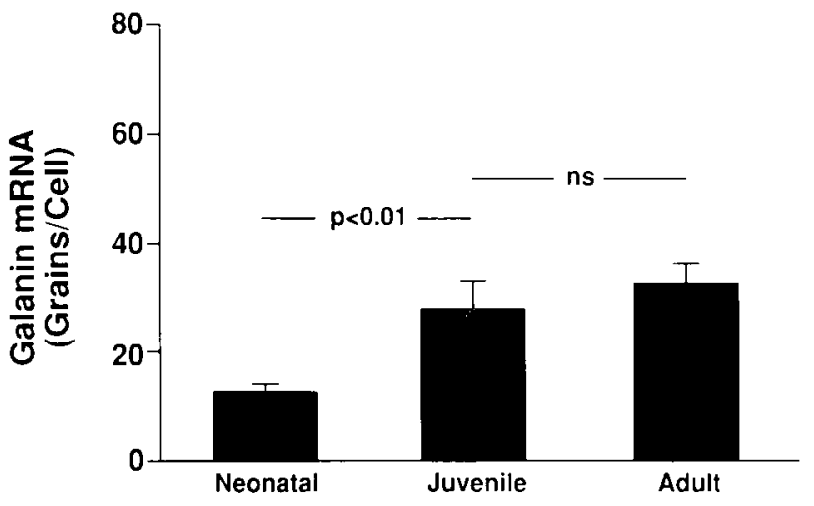

Fig. 3. Galanin mRNA levels in GHRH neurons of the female rat throughout development. The ages of the rats are as follows: neonatal, 10 days; juvenile, 25 days; and adult, 70 days. Values are presented as the mean \pm SEM.

expression in GHRH neurons, additional detailed analyses were performed.

\section{Galanin and GHRH mRNA coexpression in males}

Galanin mRNA signal levels in GHRH neurons of the male rat are illustrated in Fig. 2. Over the entire hypothalamus, the number of grains per cell increased significantly across development $(P<0.0001)$, with adult rats $(70$ days old) showing approximately $260 \%$ higher levels than juvenile rats ( 25 days old) and about $870 \%$ more than the 10-dayold neonatal rats. GHRH cells located in the Arc, PArc, and VMH showed a similar increase in galanin mRNA throughout development (Table 1).

\section{Galanin and GHRH mRNA coexpression in females}

In the female rat, galanin mRNA levels, as reflected by the number of silver grains per cell, increased throughout development $(P<0.005 ;$ Fig. 3$)$. There was no significant difference in galanin mRNA levels between juvenile and adult female rats, but both the adult and juvenile levels were significantly higher than 10 -day neonatal values $(P<0.01)$. Compared to 10-day-old animals, juvenile as well as adult rats showed significant increases of $120 \%$ and $160 \%$, respec-
TABLE 1. Galanin mRNA signal levels, subdivided by hypothalamic regions, in male and female rats at different stages of development $(\operatorname{Exp} 1)$

\begin{tabular}{crrr}
\hline & Neonate & Juvenile & Adult \\
\hline Male & & & \\
Arc & $4 \pm 2$ & $17 \pm 3$ & $64 \pm 6$ \\
PArc & $9 \pm 3$ & $16 \pm 3$ & $56 \pm 6$ \\
VMH & $6 \pm 2$ & $8 \pm 4$ & $23 \pm 3$ \\
Female & & & \\
Arc & $11 \pm 3$ & $39 \pm 5$ & $43 \pm 3$ \\
PArc & $23 \pm 4$ & $10 \pm 6$ & $14 \pm 5$ \\
VMH & $9 \pm 2$ & $8 \pm 5$ & $11 \pm 5$ \\
\hline
\end{tabular}

Values are expressed as mean grains per cell \pm SEM.

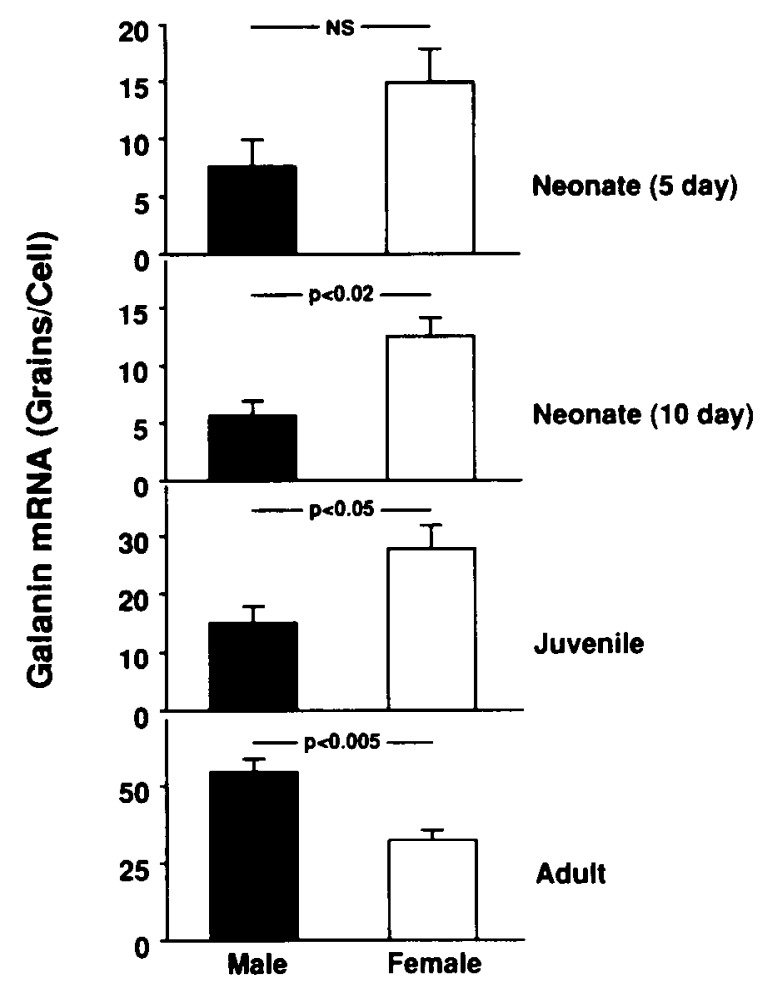

FIG. 4. Sexually dimorphic expression of galanin in GHRH neurons of rats at various ages. Juvenile and adult rats were 25 and 70 days old, respectively. Values are given as the mean \pm SEM.

tively, in the average number of grains per cell. These increases occurred primarily in CHRH cells of the Arc $(P<$ 0.0002), whereas galanin levels in PArc and VMH GHRH cells remained unaltered throughout development (Table 1).

\section{Sexual dimorphism of galanin mRNA in GHRH neurons}

When tested individually, overall galanin mRNA expression in GHRH neurons of the hypothalamus was sexually dimorphic at the three later stages of development (Fig. 4). In 10-day-old neonatal and juvenile animals, galanin mRNA signal levels in GHRH neurons were approximately $120 \%$ and $80 \%$ higher in females $(P<0.02$ and $P<0.05)$ than in males. GHRH cells in adult males contained about $60 \%$ more galanin mRNA than those in adult females $(P<0.005)$.

Galanin mRNA signal levels in GHRH neurons were sexually dimorphic in both the Arc and PArc nuclei of the adult 
rat $(P<0.02$ and $P<0.001$, respectively; Table 1$)$, with higher levels of galanin mRNA in the male. A more detailed inspection revealed that galanin signal levels in GHRH neurons varied significantly over the rostral-caudal extent of the Arc, with the highest levels of galanin mRNA in the middle third; however, this pattern was not different between males and females (Table 2). In addition, differences between adult males and females in the $\mathrm{VMH}$ were not significant.

In the juvenile brains, GHRH neurons in the Arc nucleus of the female contained more galanin mRNA than those of their male counterparts $(P<0.01)$, whereas there were no apparent differences in the PArc and VMH nuclei. GHRH neurons of the PArc nucleus in 10-day-old female neonates had significantly higher levels of galanin mRNA compared to the same neurons in males $(P<0.05)$, but galanin mRNA in GHRH neurons in the Arc and VMH was not different between the sexes.

Brain tissue from 5-day-old rats were investigated in a separate in situ hybridization assay (Exp 2). In the male group, the overall calculation showed a very low number of silver grains per cell $(8 \pm 2)$, indicating barely detectable levels of galanin mRNA in GHRH neurons. In the female neonatal animals, galanin mRNA signal was higher $(15 \pm 3$ grains/cell). However, this difference was not significant, nor was it in the Arc, PArc, and VMH areas.

\section{Testosterone regulation of galanin $m R N A$ expression in GHRH neurons}

As shown in Fig. 5, castration resulted in a $21 \%$ reduction in galanin mRNA in hypothalamic GHRH neurons. Although this reduction was not statistically significant $(P=\sim 0.07)$, testosterone replacement given to castrated animals induced a significant $(33 \% ; P<0.02)$ increase in galanin mRNA

TABLE 2. Galanin mRNA signal levels throughout the arcuate nucleus in adult male and female rats (Exp 1)

\begin{tabular}{llll}
\hline & Rostral & Middle & Caudal \\
\hline Male & $47 \pm 7$ & $75 \pm 7$ & $62 \pm 7$ \\
Female & $32 \pm 9$ & $51 \pm 6$ & $35 \pm 3$ \\
\hline
\end{tabular}

The arcuate nucleus was divided into three equal rostral-caudal segments. Values are expressed as mean grains per cell \pm SEM.

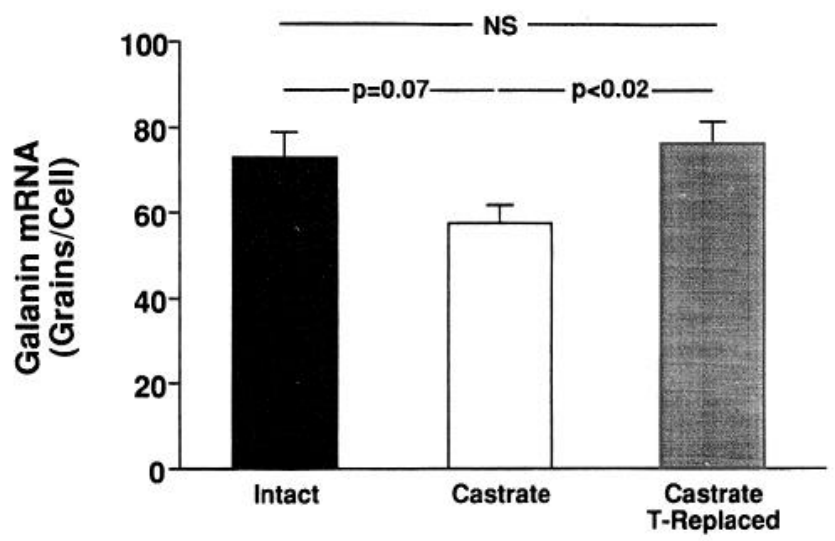

FIG. 5. Effects of testosterone on galanin message levels in GHRH neurons of adult male rats. Values are presented as the mean \pm SEM. coexpression, suggesting that galanin mRNA expression in GHRH neurons is regulated by testosterone.

In the individual hypothalamic areas studied, only GHRH neurons in the Arc nucleus were affected by castration and testosterone replacement. Galanin mRNA coexpression in Arc GHRH neurons of castrated animals, as indicated by the number of grains per cell over GHRH-positive cell bodies, was $63 \pm 6$ in the castrated group compared to $79 \pm 5$ in the sham-castrated group and $83 \pm 6$ in the castrated testosterone-replaced group. Again, the difference between castrates and testosterone-replaced castrates was significant $(P<0.05)$. No significant differences among treatment groups were found in the PArc or VMH.

\section{Serum hormone concentrations}

Serum hormone concentrations for Exp 1 are shown in Table 3. Male LH and testosterone concentrations increased over development; most of the increase occurred between days 25-70. LH levels in 10- and 25-day-old females were only about $30 \%$ of the LH levels found in the corresponding male groups. However, by day $70, \mathrm{LH}$ levels in males and diestrous females were similar. Estradiol was highest in 10day-old female rats, when it was about 10 -fold higher than the low basal levels found on days 25 and 70 . Hormone concentrations were not measured in the 5-day-old neonates (Exp 2). In Exp 3, testosterone levels were reduced from 3.0 $\pm 0.3 \mathrm{ng} / \mathrm{ml}$ in intact animals to $0.05 \pm 0.01 \mathrm{ng} / \mathrm{ml}$ in castrated animals, whereas testosterone treatment brought serum concentrations of this hormone up to $10.1 \pm 7.3 \mathrm{ng} /$ $\mathrm{ml}$.

\section{Discussion}

In this report, we have shown that galanin mRNA is expressed in GHRH mRNA-containing neurons in the rat hypothalamus. This is in agreement with earlier immunocytochemical studies that demonstrated colocalization of GHRH- and galanin-like immunoreactivity within hypothalamic neurons (7). Thus, it appears that GHRH cells of the hypothalamus synthesize, store, and presumably secrete galanin. In addition, we report that galanin message levels in GHRH neurons depend on both the sex of an animal and its stage of development. This observation provides further evidence that galanin expression in these cells is physiologically relevant and may play a role in the development of sexually dimorphic patterns of GH secretion.

TABLE 3. Serum hormone concentrations in male and female rats at different stages of development (Exp 1)

\begin{tabular}{llcc}
\hline & Neonate & Juvenile & Adult \\
\hline Male & & & \\
LH & $39 \pm 6$ & $54 \pm 18$ & $72 \pm 8$ \\
Testosterone & $0.7 \pm 0.2$ & $0.5 \pm 0.2$ & $8.4 \pm 3.0$ \\
Female & $13 \pm 4$ & $14 \pm 1$ & $78 \pm 18$ \\
LH & $46 \pm 16$ & $4 \pm 1$ & $3 \pm 1$ \\
Estradiol &
\end{tabular}

$\mathrm{LH}$ and testosterone are reported in $\mathrm{ng} / \mathrm{ml}$; estradiol, is reported in $\mathrm{pg} / \mathrm{ml}$. Values are expressed as mean \pm SEM. 
How does galanin function within the $\mathrm{GH}$ axis? Galanin administered either systemically or intraventricularly stimulates the release of $\mathrm{GH}(8-10)$. This suggests that galanin acts either at the pituitary to modulate the response of somatotropes to the actions of SS or GHRH or within the hypothalamus to control the release of SS or GHRH at the median eminence. Evidence has been adduced to support both of these possibilities, although a direct pituitary action remains controversial $(10,20-22)$. A number of neurotransmitter systems have been proposed as mediators of galanin's effects on the GH control system, including the cholinergic $(23,24)$, catecholaminergic $(25,26)$, and $\gamma$-aminobutyric acidergic (25) systems. In addition, there is evidence that galanin has direct actions on SS $(9,23,26)$ and GHRH $(10,11,25)$ neurons. Any one or a combination of these systems represents a potential target for galanin's effect on GH secretion.

Based on existing evidence, we favor the hypothesis that galanin secreted from GHRH neurons participates in the regulation of $\mathrm{GH}$ secretion by binding to receptors located on these same cells. Interactions between GHRH neurons may occur within the median eminence, where galanincontaining fibers have been shown to establish presynaptic connections (27), or within the Arc, where galanin-containing axons have been found to form synapses with the perikarya and proximal dendrites of galanin-containing neurons (28). Whether these connections involve galanin-containing GHRH cells remains to be determined; however, it is clear that galanin, either directly or indirectly, affects the release of GHRH from the hypothalamus $(25,29)$. Synaptic interactions between GHRH neurons, mediated by galanin, could form the basis for the synchronous firing of these cells, which is required for the generation of $\mathrm{GH}$ pulses. This possibility is supported by the observation that galanin antibody treatment alters the amplitude and frequency of $\mathrm{GH}$ pulses (12).

In this study, we found that galanin mRNA levels in GHRH neurons increase throughout development in both male and female rats, although their developmental patterns are different. Galanin mRNA coexpression in GHRH neurons of the male rat shows a striking increase between days 2570 of development, whereas levels in the female rise early, between days $10-25$, but never reach the maximum found in the adult male rat. Sexual dimorphism of galanin mRNA expression undergoes a switch during development; at 10 and 25 days of age, the females have higher galanin message levels, whereas the opposite is true in adults. This developmental pattern is in contrast to SS and GHRH gene expression, which from 10 days onward is greater in the male than the female (6). The facts that $\mathrm{GH}$ secretion in adult rats is sexually dimorphic and this dimorphism appears to develop after day 22 (4), a time during which galanin gene expression in GHRH neurons of males begins to exceed that of the female, provide evidence to support the hypothesis that galanin plays a role in determining the sexually differentiated patterning of $\mathrm{GH}$ secretion. Whether these sex-specific changes in galanin gene coexpression are developmentally programmed or reflect a dependence on the flux of gonadal hormones that attends puberty remains to be determined.

We also observed that the sexually dimorphic develop- mental patterns of galanin mRNA expression in GHRH neurons differ as a function of the specific hypothalamic nucleus in question. Although in males, galanin mRNA expression increases markedly in the Arc, PArc, and VMH over development, in females, the increase is restricted to the Arc nucleus. This would suggest that GHRH neurons located in the Arc nucleus play some developmental role in both sexes, whereas GHRH neurons located in the PArc and VMH may play a special role in the male. Given these observations, it is conceivable that the pubertal induction of galanin mRNA in the PArc and VMH contributes in some vital manner to the development of the adult male pattern of $\mathrm{GH}$ secretion.

The difference in GH secretion patterns between adult male and female rats appears to be due at least in part to androgens. Neonatally castrated male rats have a pattern of GH secretion in the adult state similar to that in the female, but revert to a more male-like $\mathrm{GH}$ pattern after testosterone replacement $(4,30)$. The influence that androgens have on $\mathrm{GH}$ secretion is probably multifaceted. Earlier studies in our laboratory demonstrated that testosterone stimulates SS and GHRH mRNA expression in the castrated male $(5,31)$. We have now shown that galanin gene expression in GHRH neurons is also influenced by some factor(s) secreted by the testis, and that one of these is likely to be testosterone. Therefore, a combination of increased SS, GHRH, and galanin gene expression in response to elevated testosterone levels may help to explain the different patterns of $\mathrm{GH}$ secretion in males and females. Elevated SS and GHRH activities in the male are consistent with the fact that baseline $\mathrm{GH}$ levels are lower and $\mathrm{GH}$ pulse amplitude is higher than those in females. Furthermore, increased galanin activity may be responsible for organizing the male pattern of $\mathrm{GH}$ secretion, as the administration of galanin antiserum to males results in a more feminine pattern of GH secretion (12).

The observation that testosterone stimulates galanin gene expression in GHRH neurons is consistent with an earlier report by Miller and colleagues (32), who found that testosterone increases intracellular galanin mRNA levels in the bed nucleus of the stria terminalis. Whether this effect of testosterone is common to all central neurons that express galanin remains to be demonstrated; however, previous data from our laboratory suggest that it is unwise to generalize about factors that regulate galanin gene expression among different populations of neurons. For example, galanin message levels in hypothalamic GnRH neurons change dramatically during lactation and over the estrous cycle, but the galanin mRNA content of non-GnRH cells in the hypothalamus does not appear to change under the same conditions $(33,34)$.

In summary, we have demonstrated that GHRH neurons coexpress galanin mRNA. In addition, there is an increase in the relative amounts of galanin message in males and females over development. Sexual dimorphism is already evident in GHRH cells at 10 days of age, with higher galanin message levels in the female. However, by adulthood (70 days) the dimorphism has been reversed; galanin message levels in adult males are higher than those in females. At least a part of this dimorphism might be explained by the observation that galanin gene expression in GHRH neurons is modulated 
by androgens. We infer that the differential expression of galanin mRNA and the implied augmentation of galanin secretory capacity by GHRH neurons help to orchestrate the different patterns of $\mathrm{GH}$ secretion between adult male and female rats.

\section{Acknowledgments}

The authors would like to thank Dr. Kelly Mayo for supplying the prghrf-2 plasmid, and Maria Vrontakis for providing the rat galanin plasmid from which we produced our riboprobes. We would also like to express our appreciation to Dr. William Bremner and the laboratory staff of the Population Center for Research in Reproduction Assay Core for measuring serum LH levels, and to Dr. David Hess and his laboratory staff at the Oregon Regional Primate Research Center for measuring serum testosterone and estradiol levels.

\section{References}

1. Jansson J-O, Edén S, Isaksson $O 1985$ Sexual dimorphism in the control of growth hormone secretion. Endocr Rev 6:128-150

2. Tannenbaum GS, Martin JB 1976 Evidence for an endogenous ultradian rhythm governing growth hormone secretion in the rat. Endocrinology 98:562-570

3. Saunders A, Terry LC, Audet J, Brazeau P, Martin JB 1976 Dynamic studies of growth hormone and prolactin secretion in the female rat. Neuroendocrinology 21:193-203

4. Edén S 1979 Age and sex-related differences in episodic growth hormone secretion in the rat. Endocrinology 105:555-560

5. Chowen-Breed JA, Steiner RA, Clifton DK 1989 Sexual dimorphism and testosterone dependent regulation of somatostatin gene expression in the periventricular nucleus of the rat brain. Endocrinology 125:357-362

6. Argente J, Chowen-Breed JA, Zeitler P, Clifton DK, Steiner RA 1991 Sexual dimorphism of growth hormone-releasing hormone and somatostatin gene expression in the hypothalamus of the rat during development. Endocrinology 128:2369-2375

7. Meister B, Hökfelt T 1988 Peptide- and transmitter-containing neurons in the mediobasal hypothalamus and their relation to GABAergic systems: possible roles in control of prolactin and growth hormone secretion. Synapse 2:585-605

8. Bauer FE, Venetikou M, Burrin JM, Ginsberg L, Mackay DJ, Bloom SR 1986 Growth hormone release in man induced by galanin, a new hypothalamic peptide. Lancet 2:192-195

9. Davis TM, Burrin JM, Bloom SR 1987 Growth hormone (GH) release in response to GH-releasing hormone in man is 3 -fold enhanced by galanin. J Clin Endocrinol Metab 65:1248-1252

10. Ottlecz A, Snyder GD, McCann SM 1988 Regulatory role of galanin in control of hypothalamic-anterior pituitary function. Proc Natl Acad Sci USA 85:9861 9865

11. Murakami $Y$, Kato $Y$, Koshiyama $H$, Inoue $T$, Yanaihara N, Imura H 1987 Galanin stimulates growth hormone (GH) secretion via GHreleasing factor (GRF) in conscious rats. Eur J Pharmacol 136:415418

12. Maiter DM, Hooi SC, Koenig JI, Martin JB 1990 Galanin is a physiological regulator of spontaneous pulsatile secretion of growth hormone in the male rat. Endocrinology 126:1216-1222

13. Mayo KE, Cerelli GM, Rosenfeld RG, Evans RM 1983 Characterization of CDNA and genomic clones encoding the precursor to rat hypothalamic growth hormone releasing factor. Nature 314:464467

14. Vrontakis ME, Peden LM, Duckworth ML, Friesen HG 1987 Isolation and characterization of a complementary DNA (galanin) clone from estrogen-induced pituitary tumor messenger RNA. J Biol
Chem 262:16755-16748

15. Marks DL, Wiemann JN, Burton KA, Lent KL, Clifton DC, Steiner RA 1992 Simultaneous visualization of two cellular mRNA species in individual neurons by use of a new double in situ hybridization method. Mol Cell Neurosci 3:395-405

16. Paxinos G, Watson C 1986 The Rat Brain in Stereotaxic Coordinates, ed 2, Academic Press, Sydney

17. Chowen JA, Steiner RA, Clifton DK 1991 Semiquantitative analysis of cellular somatostatin mRNA levels by in situ hybridization histochemistry. Methods Neurosci 5:138-158

18. Resko JA, Malley A, Begley D, Hess DL 1973 Radioimmunoassay of testosterone during fetal development of the rhesus monkey. Endocrinology 93:156-161

19. Goodman RL 1978 A quantitative analysis of the physiological role of estradiol and progesterone in the control of tonic and surge secretion of luteinizing hormone in the rat. Endocrinology 102:142150

20. Ottlecz A, Samson WK, McCann SM 1986 Galanin: evidence for a hypothalamic site of action to release growth hormone. Peptides 7:51-53

21. Gabriel SM, Milbury CM, Nathanson JA, Martin JB 1988 Galanin stimulates rat pituitary growth hormone secretion in vitro. Life Sci 42:1981-1986

22. Torsello A, Sellan R, Cella SG, Locatelli V, Müller EE 1990 Agedependent modulation by galanin of growth hormone release from rat pituitary cells in culture. Life Sci 47:1861-1866

23. Chatterjee VK, Ball JA, Davis TM, Proby C, Bloom SR 1988 The effect of cholinergic blockade on the growth hormone response to galanin in humans. Metabolism 11:1089-1091

24. Tanoh T, Shimatsu A, Maurakami Y, Ishikawa $Y$, Yanaihara N, Imura H 1991 Cholinergic modulation of growth hormone secretion induced by galanin in rats. Neuroendocrinology 54:83-88

25. Murakami $Y$, Kato $Y$, Shimatsu A, Koshiyama H, Hattori N, Yanaihara N, Imura H 1989 Possible mechanisms involved in growth hormone secretion induced by galanin in the rat. Endocrinology 124:1224-1229

26. Cella SG, Locatelli V, De Gennaro V, Bondiolotti GP, Pintor C, Loche S, Provezza M, Müller EE 1988 Epinephrine mediates the growth hormone-releasing effect of galanin in infants rats. Endocrinology 122:855-859

27. Arai R, Calas A 1991 Ultrastructural localization of galanin immunoreactivity in the rat median eminence. Brain Res 562:339-343

28. López F J, Lipsits Z, Merchenthaler I 1992 Evidence for a negative ultrashort loop feedback regulating galanin release from the arcuate nucleus-median eminence functional unit. Endocrinology 130:14991507

29. Kitajima N, Chihara K, Abe H, Okimura Y, Shakutsui S 1990 Galanin stimulates immunoreactive growth hormone-releasing factor secretion from rat hypothalamic slices perifused in vitro. Life Sci 47:2371-2376

30. Jansson JO, Ekberg S, Isaksson OG, Edén S 1984 Influence of gonadal steroids on age- and sex-related secretory patterns of growth hormone in the rat. Endocrinology 114:1287-1294

31. Zeitler P, Argente J, Chowen-Breed JA, Clifton DK, Steiner RA 1990 Growth hormone-releasing hormone messenger ribonucleic acid in the hypothalamus of the adult male rat is increased by testosterone. Endocrinology 127:1362-1368

32. Miller MA, Kolb PE, Raskind MA 1993 Testosterone regulates galanin gene expression in the bed nucleus of the stria terminalis. Brain Res 611:338-341

33. Marks DL, Smith MS, Clifton DK, Steiner RA 1993 Regulation of $\mathrm{GnRH}$ and galanin gene expression in GnRH neurons during lactation in the rat. Endocrinology 133:1450-1458

34. Marks DL, Smith MS, Vrontakis M, Clifton DK, Steiner RA 1993 Regulation of galanin gene expression in gonadotropin-releasing hormone neurons during the estrous cycle of the rat. Endocrinology 132:1836-1843 